The University of Maine

DigitalCommons@UMaine

Publications

Senator George J. Mitchell Center for Sustainability

Solutions

$3-2013$

\title{
Using Mixed Methods to Develop a Frame-Based Private Landowner Typology
}

Jessica Spelke Jansujwicz

University of Maine, jessica.jansujwicz@maine.edu

Aram J K Calhoun

University of Maine, Calhoun@maine.edu

Jessica Leahy

University of Maine - Main, jessica.leahy@maine.edu

Robert J. Lileholm

University of Maine

Follow this and additional works at: https://digitalcommons.library.umaine.edu/ mitchellcenter_pubs

\section{Repository Citation}

Jansujwicz, Jessica Spelke; Calhoun, Aram J K; Leahy, Jessica; and Lileholm, Robert J., "Using Mixed Methods to Develop a FrameBased Private Landowner Typology" (2013). Publications. 12.

https://digitalcommons.library.umaine.edu/mitchellcenter_pubs/12 


\section{Using Mixed Methods to Develop a Frame-Based Private Landowner Typology}

Jessica S. Jansujwicz

Department of Wildlife Ecology and School of Forest Resources, University of Maine, Orono, Maine, USA

Sustainability Solutions Initiative, 5710 Norman Smith Hall, University of Maine,

Orono, ME 04469, USA. E-mail: jessica.jansujwicz@ maine.edu

Aram J. K. Calhoun

Department of Wildlife Ecology, University of Maine, Orono, Maine, USA

Jessica E. Leahy And Robert J. Lilieholm

School of Forest Resources, University of Maine, Orono, Maine, USA 


\section{ABSTRACT}

An important goal of community-based management is to engage a wider network of stakeholders in conservation and management decisions. Using mixed methods, we constructed a frame-based private landowner typology to identify landowner response patterns to vernal pool conservation and management in Maine. Drawing on data from interviews and focus groups, we identified two opposing frames that described landowner views on vernal pools (personal gain and personal loss). A mail survey identified three groups of private landowners (Supportive, Uncertain, and Opposing) with similar sociodemographic and property variables but different aesthetic preferences, economic concerns, and views on property rights and conservation. Our results suggest that frame-based typologies are useful for enhancing communications with different landowner groups and in identifying trusted information sources and communication preferences. Our approach represents a critical first step toward understanding and integrating a range of landowner perspectives into conservation practice and enhancing private landowner cooperation in proactive planning.

Keywords: community-based conservation planning, framing, landowner typology, private land, vernal pools 


\section{INTRODUCTION}

Scientists are increasingly called upon to frame their messages in ways that encourage broader participation from a wider, more diverse, and otherwise inattentive public (Groffman 2010; Nisbet and Scheufele 2009). If scientific messages are inconsistent with stakeholder frames, or the way that stakeholders think, perceive, and speak about an issue or concern, they will likely be ignored (Lakoff 2010). Thus, to enhance stakeholder cooperation in proactive conservation planning programs focused on private lands, natural resource professionals must forge meaningful connections between a program's objectives and a landowner's background system of frames.

Frames are simplified cognitive constructs that people use to organize information, interpret their observations, and solve problems (Goffman 1974). They describe underlying structures of belief, perception, and appreciation (Schön and Rein 1994). As a research methodology, framing is used to understand how individuals and groups interpret or "make sense" of a particular conflict or challenge and to explain what the conflict is about, why it is occurring, and how it might be resolved (Gray 2003; Lewicki et al. 2003). Using a framing approach, researchers have demonstrated how competing stakeholder frames influence policy-making and contribute to conflict persistence (e.g., Gray 2004; Lewicki et al. 2003; van Lieshout et al. 2011; Vincent and Shriver 2009). Framing has also 
been used to explore policy options that may accommodate the interests of both private landowners and resource professionals (e.g., conservation easements, habitat mitigation banking, and voluntary grassroots initiatives) (Fischer and Bliss 2009). However, to date, no published studies explore the use of framing theory to explain private landowner choices to engage in community-based resource management. Such research is critical for understanding how stakeholder framing of natural resources, environmental regulation, and conservation planning influences an individual's decision of whether or not to cooperate in voluntary community-based management.

We explore the interplay between stakeholder framing, landowner decision making, and landowner cooperation in community-based management through a study focused on vernal pools in Maine. Four key questions drove this research: (1) How do landowners frame their response to vernal pools, vernal pool regulation, and community-based vernal pool conservation planning? (2) Do landowners share common patterns of framing relevant to vernal pool issues on their property? (3) Are there factors that can be used to explain the emergence of these distinct groups? (4) How can a frame-based landowner typology inform conservation and enhance cooperation in community-based planning?

\section{STUDY CONTEXT}


Vernal pools are small seasonal wetlands in forested landscapes that provide critical breeding habitat for a unique assemblage of amphibians and invertebrates, and important resting and foraging habitat for a number of sensitive species (Calhoun and deMaynadier 2008). In Maine, vernal pools are managed through a combination of state-level regulation and locally driven proactive planning. Since 2007, the Maine Natural Resources Protection Act (NRPA) has protected a subset of ecologically outstanding vernal pools (known as Significant Vernal Pools or SVPs) as Significant Wildlife Habitat. Under NRPA, landowners must obtain a permit from the Maine Department of Environmental Protection before they can alter up to $25 \%$ of the area within 250 feet of an SVP. However, there are no statewide inventories of potential vernal pools, and the burden is on the landowners to determine whether or not they have a SVP before they can develop. To assist landowners and communities in mapping and assessing vernal pools in advance of development, the University of Maine and Maine Audubon Society initiated the community-based Vernal Pool Mapping and Assessment Program (VPMAP) in 2007.

VPMAP works collaboratively with local towns to inventory vernal pools using remotely sensed potential pools that are field assessed by VPMAP-trained citizen scientists. The goals of VPMAP are to raise the awareness of vernal pool habitat (the pool and adjacent terrestrial area used by amphibians in the nonbreeding season), educate citizens through hands-on engagement in inventory 
and assessment, and enhance regulatory compliance with the Significant Wildlife Habitat rules. VPMAP reduces uncertainty in development proposals by offering landowners free Potential Vernal Pool (PVP) assessments, and determines whether their pool (or pools) is "significant" under NRPA. "Significance" is determined by threshold egg mass counts of pool-breeding amphibians (i.e., wood frogs, spotted salamanders, and blue-spotted salamanders), or the presence of fairy shrimp and/or an endangered or threatened species. No field assessments can be conducted on private land without landowner permission. As of this writing, VPMAP has partnered with 12 municipalities (Morgan and Calhoun 2012).

\section{CONCEPTUAL FRAMEWORK}

Dewulf et al. (2009) distinguished between frames as static knowledge structures and frames as dynamic interactional co-constructs, where parties negotiate the meaning behind frames through a process of continuous interaction. The first approach describes frames as memory structures (Minsky 1975), knowledge schema, or structures of expectations that guide action (Neale and Bazerman 1985; Tversky and Kahneman 1981). It examines the way that people experience, interpret, process, or represent issues, relationships, and interactions in a particular situation (Dewulf et al. 2004). Using a cognitive approach, researchers generate a variety of descriptions of a particular situation from the perspectives of those involved, and then classify the descriptions into several categories (i.e., 
frames) based on their similarities.

In contrast, framing as an interactional co-construct refers to frames as "communicative devices that individuals and groups use to negotiate their interactions" (Dewulf et al. 2009, 160). Here, framing is thought to be a dynamic interactive process whereby stakeholders engage in ongoing dialogue to develop an understanding of problems and alternative solutions (Brugnach et al. 2008). Scholars use an interactional approach to examine how individuals or groups act in relation to each other to explore whether actors highlight different aspects of a situation as relevant, problematic, or urgent (e.g., emphasize certain things over others), and/or to determine if individual and collective frames change over time in response to interaction among participants.

We use a cognitive framing approach to establish a baseline understanding of stakeholder response to conflict and collaboration in natural resource management. We view this as a useful first step in identifying stakeholder reference points (Burns and Cheng 2007) and for mapping patterns in stakeholder frames. We focus on cognitive representations of the way Maine landowners perceive issues related to vernal pools. In Maine, vernal pools are at the center of intense political debate and our research represents an important first step toward tracking temporal shifts in stakeholder attitudes as a result of dynamic "framing contests" (Vincent and Shriver 2009) among stakeholders with competing views on vernal pools. 
We use these frames based on views toward vernal pools, vernal pool regulations, and community-based vernal pool management to construct a private landowner typology. Typologies are a useful tool for systematically classifying types of landowners with common characteristics or traits. They are often used to identify types of landowners who share similar views, have similar socioeconomic characteristics, and make decisions in a similar manner (Emtage et al. 2006). Typically, landowner typologies are defined based on landownership motivations (e.g., Karppinen 1998; Kline et al. 2000; Kuuluvainen et al. 1996) or on attitudes toward specific policies and management practices (e.g., Boon and Meilby 2007; Finley and Kittredge 2006; Jennings and van Putten 2006; Madsen 2003). Such typologies are useful for targeting outreach efforts (Davis and Fly 2010; Kittredge 2004) and for linking each owner type with the appropriate policy and advisory services (Boon and Meilby 2007; Hogl et al. 2005).

Applied broadly to natural resource conservation issues, landowner typologies can help avoid using a uniform approach to working with landowners, while at the same time recognizing that it is impossible to have policies and programs tailored to each individual (Emtage et al. 2006). By constructing a typology based on the ways that private landowners perceive vernal pools, our frame-based approach provides a theoretical model for stakeholder cooperation in community-based conservation and offers a practical approach for targeting communications with 
stakeholders who are potentially impacted by resource management and policy decisions.

\section{METHODS}

We used a sequential exploratory strategy involving a first phase of qualitative data collection and analysis, followed by a second phase of quantitative data collection and analysis (Creswell 2009). Using multiple methods to examine how landowners frame their response to vernal pools, we improved the accuracy of our results (Jick 1979), and offer a more robust explanation of how private landowners think and talk about vernal pools.

Qualitative Data Collection and Analysis

Qualitative data collection occurred in two phases. First, we conducted nine key informant interviews with private landowners in four VPMAP-participating towns. Seven landowners were identified by municipal officials working with VPMAP as people who were easy to talk to, who would understand the information we needed, and who would be glad to speak with us about their experiences with vernal pools and VPMAP. Two additional landowners were identified during the focus-group recruitment process and as a result of follow-up from the mail survey. Interview questions were open-ended and structured to identify major themes 
related to the landowner's property, vernal pools, and the vernal pool regulations. Because the regulations were new, we had very little understanding of landowner awareness of the regulations and vernal pools in general. Developing a baseline understanding of landowner awareness and attitudes was critical for narrowing the focus of our inquiry and designing subsequent stages of our research. Interviews allowed us to identify major themes and develop a targeted questionnaire for focusgroup discussions.

We conducted eight landowner focus groups $(n=48)$. We randomly selected focus group participants from a list of private landowners with PVPs. Within each town, one focus group consisted of private landowners who were participating in VPMAP (i.e., granted permission to survey their property) $(n=28)$, while the second consisted of private landowners who did not allow an assessment $(n=20)$. During the 2-hour focus group we asked landowners about their property (e.g., location, size, and features), their reasons for ownership, and their views on vernal pools, vernal pool regulations, and VPMAP.

Interviews and focus groups were audio-recorded, transcribed, then stored and analyzed in NVivo 8 Qualitative Research software. For qualitative analysis we used a method of coding linked closely to grounded theory (Glaser and Strauss 1967; Strauss and Corbin 1990) that focused on identifying emerging themes, patterns, and relationships in the ways private landowners viewed their property 
and vernal pools.

Quantitative Data Collection and Analysis

We conducted a mail survey of private landowners with PVPs in the four focal towns. The first section of the survey queried landowners about their property (length of tenure, number of parcels, and acreage) and their reasons for ownership. The second section explored vernal pool attitudes and asked landowners to indicate the extent to which they agreed or disagreed with 13 statements about vernal pools. Statements were developed to explore themes that emerged from analysis of interview and focus-group transcripts. The third section asked landowners about trusted sources of information and communication preferences. The final section collected socioeconomic and demographic information. The questionnaire was pretested with a small group of private landowners with PVPs $(n=7)$ from a town participating in VPMAP but not included in this study.

All landowners within the study area who owned property included on a town list of PVPs were selected for the sample $(n=587)$. Following Dillman's tailored design method (Dillman et al. 2009), 232 completed and usable surveys were returned. Forty-two questionnaires were undeliverable, and 11 were returned but unusable, resulting in an overall response rate of $40 \%$. 
We used the $k$-means cluster analysis procedure to categorize respondents based on the extent to which they agreed or disagreed with the 13 vernal pool attitude statements. Cluster memberships were assigned to each participant, and chi-square $\left(X^{2}\right)$ analysis determined the degree of heterogeneity and homogeneity of responses to attitude statements within and between clusters. One-way analysis of variance (ANOVA) tested whether landowner clusters could be described based on age, land tenure, acres owned, ownership objectives, and property concerns. Chi-square tests were used to explore relationships between cluster membership, gender, education, residency, income, and work status, and to explore relationships between cluster membership and participation in VPMAP. One-way ANOVA was used to identify trusted sources of information on vernal pools and landowner communication preferences.

\section{FINDINGS}

\section{Qualitative Findings}

Participant Description

All but one landowner we interviewed participated in VPMAP. Of the nine landowners, six were male. Six landowners resided on the property with the PVP, two lived in towns neighboring the PVP parcel, and one was an 
absentee landowner. All participants were over 50 years old. Four were retired. Focus-group participants included 24 males and 24 females. Ages ranged from 39 to 77 years old. Acreage owned ranged from less than 1 acre to 500 acres. Residency ranged from 5 to 51 years.

Landownership Objectives

Interview and focus-group participants' most frequently identified reasons for owning property with the PVP were "beauty and scenery," "privacy," "space for their family to enjoy," "recreation," as a "future homesite," and as a source of income either directly through agricultural activity or as a financial investment. Less frequent responses included property as a place to live or as an inheritance landowners were responsible for managing.

Landowner Frames

We did not use framing as an a priori cognitive model of the way landowners think and talk about vernal pools. Rather, the framing concept emerged inductively during our analysis phase. In using the method of open coding, we recognized that landowners expressed their views on vernal pools, vernal pool regulations, and VPMAP in similar ways. Using data from interviews and focus groups we discerned a pattern in landowner response, and used participant's own words to 
build framing categories. Although the primary purpose of interviews was to develop a baseline understanding of landowner perceptions, thoughts, and actions, emerging themes were consistent with data from focus groups. Multiple sources of data enhanced the credibility of our results and confirmed our emerging findings (Merriam 2009); thus, we used interview data to support our focus-group findings.

Our analysis of interviews and focus group transcripts identified a range of private landowner responses that could be collapsed into two opposing frames: personal gain and personal loss.

A personal gain frame is described by themes of enjoyment, education, aesthetics, the need for information, and the importance of wildlife habitat and conservation. One landowner said, "The pond is behind our house and there are lots of frogs for the boys to catch. It's fun!" Another spoke of the educational value of vernal pools. She said:

When my daughter was little, we used to do science projects. We'd go down to this vernal pool ... we'd get inside the trees, and we'd find things that we could take home and look at underneath a microscope.

Some landowners highlighted aesthetically pleasing aspects of vernal pools, 
such as the chorus of frogs and the wildlife (especially birds) attracted to the pools. Landowners also referenced the habitat value of vernal pools and often described them as "frog ponds" where frogs and salamanders lived. Landowners shared their "environment interest" in vernal pools and expressed the view that they are an important part of nature and that "it is our environment that we should protect."

Landowners also talked about the personal benefits of participating in VPMAP. Some were interested in receiving information about a PVP(s) on their property, either because they were curious or because they had plans to sell or develop. One landowner said, "I would just like to know the implications as it relates to vernal pools, were I to sell." One couple participated in VPMAP because they needed a "significance" determination for the PVP on their property in order to complete a conservation option agreement with a land trust. Another landowner viewed VPMAP as a way to promote conservation and control development in her town. She said:

From my point of view [my town] is pro-development. So, I was, first of all surprised that my town signed up for [VPMAP]. And my second thing was: Oh well. Maybe this will slow my town down!

A personal loss frame is described by themes of displeasure, property rights, economic impacts, antidevelopment, anti-conservation, and risk. Landowners using 
a personal loss frame described a vernal pool as "it stinks," "it's dirty," or "it is probably the best breeding ground for mosquitoes." Some landowners framed vernal pool regulations as a "taking" of private property rights. One landowner said, "It's not about vernal pools. I am not against the frogs and things, but I can feel the fingers of government creeping in to take more and more away from the landowner." Many landowners were concerned about the economic impact of regulatory restrictions and viewed the 250-foot regulated zone as "excessive." One landowner, concerned that regulation would limit the use of his property, said, "If this goes vernal pool it could cut me out of a house lot .. \$30,000 or even $\$ 50,000 . "$ Another landowner framed the regulations as a "back-door attempt" to stop development. Others did not necessarily refute the need to conserve vernal pools, but resented government restrictions on the way they managed their property. As one landowner said, "[The vernal pool] does its thing and I respect that, but I know enough to leave it alone. I don't need someone to tell me I can't do something, that's all." Landowners did not frame vernal pool protection as urgent. One landowner said, "I might want to protect all those salamanders ... but we've got people to protect too." A few landowners suggested that the vernal pool regulation would result in unintended consequences such as the deliberate filling of vernal pools. One said:

Sometimes regulation can hinder you in trying to save something because you get a lot of people upset, and you're going to start taking their 
land, and before you get in there to find those eggs, they're not going to be there. They're going to be gone. You know why? Because the landowner got rid of them.

Although the extent of this response is unknown, our data supported the assertion that some landowners would fill a PVP to avoid regulatory restrictions. One landowner we interviewed had filled a PVP on his property because, as he explained, "I don't want someone else coming along later to find a wet spot on my property and tell me it's a vernal pool."

In sharing their response to VPMAP, several landowners described the program as authoritative or bureaucratic. In describing the tone of the town's invitation to participate in VPMAP, one landowner said:

It kind of says, "Well, we've already passed the rules and you guys can help out and get a free survey. Or if you want to develop later you're going to pay through the nose. And you are going to have a hard time convincing us of your ability to do anything with your property."

Some landowners were concerned that participating in VPMAP would draw attention to their property and increase the risk that it would be more heavily regulated. Supporting this, one landowner asked, "If I sign up for this, are we going 
to be identified as a piece of property that is going to be regulated more than it would be by the state?"

Quantitative Findings

Participant Description

Of survey respondents, $58 \%$ were male. Respondents were often (53\%) between 50 to 69 years old; the youngest was 29 years old and the oldest was 96 years old. The majority of survey respondents $(72 \%)$ listed education beyond high school. Of those, $50 \%$ had a BS or higher. Total household income below the median for Maine was reported by $39 \%$ of the respondents. The majority of respondents were permanent residents (79\%) on the property with the PVP, as compared to seasonal $(4.8 \%)$ or other $(16.3 \%)$.

Landowner Clusters

Using $k$-means cluster analysis we identified three clusters of private landowners based on their mean response to attitude statements about vernal pools (Table 1). Cluster 1 consisted of 128 landowners whose responses were characterized by positive views on vernal pools and conservation. We labeled this group "Supportive Landowners." Mean value scores indicated that Supportive 
Landowners strongly agreed with statements that stressed the benefits of vernal pools for education (4.66), personal enjoyment (4.55), habitat (4.77), and the importance of conservation (4.66). Cluster 2, "Uncertain Landowners," consisted of 47 respondents with neither positive nor negative views of vernal pools. In Cluster 2, low mean value scores indicated landowners neither agreed nor disagreed with positive statements about vernal pools (although they had a mean score of 3.73 for the statement "Vernal pools provide important wildlife habitat"). Low mean scores in Cluster 2 indicated that landowners did not find vernal pools aesthetically pleasing (2.02), that a vernal pool would not increase the value of their property (1.54), but that they would most likely not fill in their pool (1.59). Cluster 3, “Opposing Landowners," consisted of 56 landowners whose responses were defined by strong views on the perceived impacts of vernal pools on property rights, economic well-being, and development. They also had a high mean score (4.10) for the statement "vernal pools can be dangerous because mosquitoes that carry disease breed there." Similar to Uncertain Landowners, low mean scores indicated that Opposing Landowners did not agree with the statement that vernal pools "might increase the value of my property." They also disagreed (mean value of 2.32) with the statement "my town should try to conserve vernal pools," which was consistent with their views on property rights, development, and economics.

Factors Describing Landowner Clusters 
All three private landowner clusters (Supportive, Uncertain, and Opposing) indicated that important reasons for owning land were "as a place of residence," "for privacy," and "to have space for my family to enjoy" (Table 2). Supportive Landowners and Uncertain Landowners also indicated that important reasons for owning their land were "to enjoy beauty and scenery." Only Supportive Landowners indicated that an important reason for owning their land was "to protect nature and biological diversity." Opposing Landowners indicated that an important reason for owning their land was "as a financial investment," and "to pass land onto my heirs and other children." Opposing landowners identified "to earn an income" as a significantly more important reason for owning land than Supportive Landowners; however, the mean value score (3.10) was neutral. Similarly, Opposing Landowners identified "for a future homesite" as significantly more important than Supportive Landowners; however, mean value score for this variable (3.38) was also neutral. Recreation (consumptive and non-consumptive), production (e.g., farming, agriculture, forest products), and "to take care of land I inherited" were not identified as important reasons for owning land among all three landowner clusters.

Only education was significantly different among landowner clusters $\left[X^{2}(2\right.$, $n=212), p<.05]$. Of Supportive Landowners, 58\% were college graduates or had an advanced degree, as were $44 \%$ of Uncertain Landowners and $37 \%$ of Opposing Landowners. There were no statistically significant differences in 
property characteristics (acres owned, residency, land tenure), income, and work status.

Landowner VPMAP permission rates were statistically different across the three clusters $\left[X^{2}(2, n=191), p<.001\right]$. Of the Supportive Landowners, $81 \%$ indicated that they were participating in VPMAP, as did $44 \%$ of Uncertain Landowners and 57\% of Opposing Landowners.

Trusted Sources of Information and Communication Preferences

Survey respondents were asked to indicate on a 5-point Likert scale the trustworthiness (very untrustworthy to very trustworthy) of various sources for providing accurate information on vernal pools (Table 3). Supportive Landowners identified more trusted sources than any other cluster. Trusted sources of information for Supportive Landowners included federal and state agencies, universities, and conservation organizations. Uncertain Landowners also identified state fisheries and wildlife agencies as a trusted source of information. Opposing Landowners identified no trusted sources, as indicated by low mean scores in all categories. Town planners were identified as untrustworthy sources among all three landowner clusters. Uncertain and Opposing Landowners also identified citizen scientists and neighbors as untrustworthy sources. 
Survey respondents were asked to indicate effective ways of providing them with information about vernal pools (Table 4). Fact sheets were preferred among all three landowner clusters. Supportive Landowners also identified websites and meetings with a natural resource professional as effective. Landowners did not perceive citizen scientists and neighbors as a trustworthy source of accurate information on vernal pools.

\section{DISCUSSION AND CONCLUSION}

An important goal of community-based management is to engage a wider network of stakeholders in conservation and management decisions. Our study identified patterns in landowner response to vernal pool conservation and management with the goal of understanding private landowner cooperation in voluntary proactive planning. We grouped respondents based on their agreement with positive and negative vernal pool statements and to describe the groupings and characteristics on which they differed. Segmentation of landowners into Supportive Landowners, Uncertain Landowners, and Opposing Landowners was not surprising. Previous studies of stakeholder framing revealed that diverse stakeholders approached natural resource management and policy issues with different reference points and framed their management options as gains or losses from these divergent points (Burns and Cheng 2007). In our study, landowners framed their responses to vernal pool regulations and VPMAP as a personal gain or 
loss based on their aesthetic preferences, and views of conservation, property rights, development, and perceived economic impacts.

In distinguishing between groups of private landowners based on how they framed vernal pools, we found our results consistent with previous research on landowner behavior and participation in voluntary conservation programs. In our study, a personal gain frame defined by themes of education, enjoyment, and proconservation characterized private landowners who were more supportive of community-based conservation planning ( $81 \%$ of Supportive Landowners indicated that they gave permission for a citizen science survey). Erickson and De Young (1993) described similar results, and found that personal values such as an intrinsic satisfaction from conservation made landowner participation in conservation action more likely. Similarly, Brook et al. (2003) found that the more a landowner valued nature, the more likely the landowner was to manage or improve habitat and allow biological surveys. Responses of Opposing Landowners were also consistent with previous research on landowner behavior and conservation action. Napier and Camboni (1998) and Reading et al. (1994) found that people expressing strong concerns about private property rights were more likely to resist external influences on land management. Brook et al. (2003) found that if landowners feared increased regulations as a result of a protected species or habitat on their property, they would refuse to allow biological surveys to preclude management constraints. In our study, however, 57\% of Opposing Landowners were VPMAP participants, 
suggesting that strong views of property rights and economic concerns did not necessarily preclude landowner participation in proactive planning and that other factors may be more important in landowner decision making.

Uncertain Landowners were more difficult to characterize, as these landowners expressed conflicting vernal pool attitudes. On the one hand, Uncertain Landowners were concerned about the impacts of vernal pools on property values. However, they also recognized the importance of vernal pools for habitat and had mixed views on conservation, expressing both pro and anti-conservation sentiment. These findings are supported by Fischer and Bliss (2009), who demonstrated that inconsistencies in frames exist between groups of individuals, as well as for a single individual. This frame dissonance suggests that individual landowners may be dealing with two ideals simultaneously. A landowner may believe that vernal pools are important wildlife habitat, but that human needs for space are more important than amphibians' need for habitat. Landowners may place an intrinsic value on conservation, but believe that they (and not the government) are the best stewards of their land. Such frame inconsistencies make it increasingly difficult for natural resource professionals to frame vernal pool conservation in a way that resonates with an Uncertain Landowner's background system of frames and encourages their cooperation in proactive conservation planning. Further research is necessary for identifying the factors that may motivate the participation of Uncertain Landowners who may be "on the fence" with regard to management 
decisions and vernal pools.

Factors Describing Landowner Clusters

Landowner clusters were not clearly distinguishable based on sociodemographic variables. Landowners across the three clusters had similar reasons for owning their property, including privacy and open space. However, Opposing Landowners identified economic objectives while Supportive Landowners identified the protection of nature and biological diversity as important reasons for owning their land. These differences in ownership objectives were consistent with landowners' vernal pool frames.

Trusted Sources of Information and Communication Preferences

We found significant differences in landowners' trusted information sources on vernal pools. Not surprisingly, Supportive Landowners identified more trusted sources than either Uncertain Landowners or Opposing Landowners. Landowners across all three clusters did not give high scores to neighbors or other landowners, indicating that interpersonal communications did not play an important role in the dissemination of information on vernal pools. This finding contrasts with earlier work that identified social networks as important and trusted information sources (e.g., Boon and Meilby 2007; Rosenberg and Margerum 2008). Moreover, we 
found that town planners and citizen scientists were two of the least trusted sources of information among landowners in all three clusters. This finding is of particular concern because town planners and citizen scientists may be more accessible than university researchers, and thus potentially have more opportunity to interact with private landowners. Fact sheets were clearly the preferred method of communication for all landowner types. This is presumably because they are a quick, convenient, and noninvasive way of getting information on vernal pools (Rosenberg and Margerum 2008). Supportive Landowners' preference for meetings with a natural resource professional was consistent with their trust in government, universities, and nongovernmental environmental organizations as sources of accurate information. The finding that citizen scientists, neighbors, and other property owners were not perceived as effective sources of information for private landowners was consistent with the low level of landowner trust in these sources.

Using a Frame-Based Typology to Inform Conservation Planning on Private Land

Our frame-based typology is a useful approach for segmenting private landowners based on the way they construct representations of the same vernal pool policy and management issue. It is also useful for defining and interpreting patterns in framing across private landowner groups. However, while our results have managerial relevance, our quantitative findings were drawn from a limited number of scale items and a limited sample with uncertain representativeness, and 
thus should be interpreted carefully. We believe that future researchers can draw on our mixed methods approach to develop a multi-item scale that can be further verified in the field.

Applying our mixed-methods approach, we provide a framework upon which to base recommendations and target communication with different landowner groups. To encourage cooperation of Uncertain Landowners and Opposing Landowners in proactive planning, messages should be tailored to alleviate fear and to resonate with landowners' property and ownership objectives. Our framebased typology identified economic objectives as an important priority for Opposing Landowners, and Uncertain Landowners were concerned about the uncertain impacts of vernal pools on property values. We believe that opportunities exist to improve communication by acknowledging and integrating landowner priorities and concerns within VPMAP objectives. The objective of VPMAP is to increase certainty and notice in development decisions by helping landowners identify SVPs in advance of development. As designed, vernal pool regulations do not simply create a "no build zone." Indeed, landowners with an SVP can acquire a permit and still develop a portion of their property. By focusing on the flexibility that is embodied in the regulations, natural resource professionals can find ways to better connect landowner frames and VPMAP objectives. 
A frame-based landowner typology can also explore effective entry points of communication with landowners utilizing trusted information sources.

Collaboration with state fish and wildlife agencies can serve to enhance the trustworthiness and credibility of VPMAP. However, while trusted sources were clearly identified for Supportive Landowners and, to a lesser extent, Uncertain Landowners, our mail survey did not identify trusted sources for Opposing Landowners. Previous research identified traditional information sources (e.g., agricultural extension services) as important information sources (Rosenberg and Margerum 2008). It may be that traditional institutions that were not listed in our mail survey, such as Cooperative Extension, are trusted sources for Opposing Landowners. Local land trusts, conservation commissions, garden clubs, and other community organizations may also be effective sources for communicating vernal pool issues with landowners. Following our mixed-methods approach, future researchers could identify trusted sources for inclusion in the mail survey by including more Opposing Landowners in the interview and focus-group stage of research.

Prior studies of landowner participation in volunteer conservation programs demonstrated that personal networks of family and friends are important sources of information (e.g., Rosenberg and Margerum 2008; van Herzele and Van Gossum 2008). We did not find this to be the case in our study. A better understanding of this trend may help to develop effective strategies for empowering neighbors and 
friends, enhancing their credibility, and encouraging information sharing among social networks. Of particular concern to the credibility and sustainability of VPMAP is the lack of trust in citizen scientists and town planners - key partners in voluntary, community-based approaches. In addition to their role in data collection, citizen scientists are well positioned to "spread the word" about the importance of vernal pools and the benefits of proactive planning. Town planners play an important role in community-based management by serving as liaisons between landowners and VPMAP coordinators (i.e., university researchers). Future research should explore mechanisms to enhance landowner trust in citizen scientists, town planners, and other local points of contact. Research should also explore the role that influential community leaders might play in communicating vernal pool issues with landowners.

Voluntary programs are increasingly supported to address natural resource issues on private land; however, the success of these programs (and ultimately the sustainability of natural resources) is largely dependent upon landowner cooperation. Identifying and labeling landowner's background frames can assist natural resource managers in encouraging landowner cooperation in programs such as VPMAP. Our frame-based approach represents a critical first step toward mobilizing cooperative behavior and enhancing conservation outcomes on private land. Although we focus on a case of vernal pool conservation in Maine, our framebased private landowner typology is a useful approach for acknowledging, 
understanding, and integrating a wide range of landowner interests, concerns, and management needs into conservation practice. 


\section{FIGURES}

Table 1. Private landowner groupings based on landowners' views toward vernal pools, with mean response values for each landowner cluster

\begin{tabular}{|c|c|c|c|}
\hline & $\begin{array}{l}\text { Cluster 1, } \\
\text { SUPPORT, } \\
n=128\end{array}$ & $\begin{array}{c}\text { Cluster 2, } \\
\text { UNCERT AIN, } \\
n=47\end{array}$ & $\begin{array}{c}\text { Cluster } 3 \text {, } \\
\text { OPPOSE, } \\
n=56\end{array}$ \\
\hline \multicolumn{4}{|l|}{ Statements (personal gain frame) } \\
\hline $\begin{array}{l}\text { Vernal pools provide important wildlife } \\
\text { habitat }\end{array}$ & $4.77^{\mathrm{a}}$ & $3.73^{\mathrm{b}}$ & $3.24^{\mathrm{c}}$ \\
\hline $\begin{array}{l}\text { The health of amphibians is related to } \\
\text { the quality of our environment }\end{array}$ & $4.77^{\mathrm{a}}$ & $3.40^{\mathrm{b}}$ & $3.33^{\mathrm{b}}$ \\
\hline $\begin{array}{l}\text { There is a value in teaching children } \\
\text { about vernal pools }\end{array}$ & $4.66^{\mathrm{a}}$ & $3.09^{\mathrm{b}}$ & $3.48^{\mathrm{c}}$ \\
\hline $\begin{array}{l}\text { If I had a vernal pool on my property, I } \\
\text { might try to conserve it }\end{array}$ & $4.66^{\mathrm{a}}$ & $3.17^{\mathrm{b}}$ & $2.36^{\mathrm{C}}$ \\
\hline $\begin{array}{l}\text { I want my children and grandchildren to } \\
\text { have vernal pools to explore }\end{array}$ & $4.55^{\mathrm{a}}$ & $2.76^{\mathrm{b}}$ & $3.20^{\mathrm{C}}$ \\
\hline $\begin{array}{l}\text { My town should try to conserve vernal } \\
\text { pools }\end{array}$ & $3.96^{\mathrm{a}}$ & $2.50^{\mathrm{b}}$ & $2.32^{\mathrm{b}}$ \\
\hline Vernal pools are pleasing to look at & $3.58^{\mathrm{a}}$ & $2.02^{\mathrm{b}}$ & $1.96^{\mathrm{b}}$ \\
\hline $\begin{array}{l}\text { Having a vernal pool on my property } \\
\text { might increase the value of my property }\end{array}$ & $2.59^{\mathrm{a}}$ & $1.54^{\mathrm{b}}$ & $1.51^{\mathrm{b}}$ \\
\hline \multicolumn{4}{|l|}{ Statements (personal loss frame) } \\
\hline $\begin{array}{l}\text { Requiring landowners to conserve } \\
\text { vernal pools conflicts with property } \\
\text { rights }\end{array}$ & $2.82^{\mathrm{a}}$ & $3.13^{\mathrm{a}}$ & $4.57^{\mathrm{b}}$ \\
\hline $\begin{array}{l}\text { Having a vernal pool on my property } \\
\text { would decrease the value of my } \\
\text { property }\end{array}$ & $2.69^{\mathrm{a}}$ & $3.59^{\mathrm{b}}$ & $4.33^{\mathrm{c}}$ \\
\hline $\begin{array}{l}\text { Vernal pools can be dangerous because } \\
\text { mosquitoes that carry disease breed } \\
\text { there }\end{array}$ & $2.84^{\mathrm{a}}$ & $2.88^{\mathrm{a}}$ & $4.10^{\mathrm{b}}$ \\
\hline $\begin{array}{l}\text { Protecting vernal pools should not rank } \\
\text { ahead of human needs for } \\
\text { development }\end{array}$ & $2.45^{\mathrm{a}}$ & $3.14^{\mathrm{b}}$ & $4.06^{\mathrm{C}}$ \\
\hline $\begin{array}{l}\text { If I had a vernal pool on my property, } \\
\text { I might try to fill it }\end{array}$ & $1.47^{\mathrm{a}}$ & $1.59^{\mathrm{a}}$ & $3.38^{\mathrm{b}}$ \\
\hline
\end{tabular}

Note. Results of $k$-means cluster analysis. SUPPORT $=$ Supportive Landowners cluster; UNCERTAIN = Uncertain Landowners cluster; OPPOSE $=$ Opposing Landowners cluster. Respondents were asked to indicate the extent to which they agreed or disagreed with statements about vernal pools. Response based on a 5 -point Likert scale where $1=$ strongly disagree; 2 = disagree; $3=$ neither agree/disagree; $4=$ agree; $5=$ strongly agree. Means (reading across rows) with different superscripts are significantly different at $p<.05$. 
Table 2. Mean values for landownership variables describing the clusters

\begin{tabular}{lccc}
\hline Reasons for owning land & SUPPORT & UNCERTAIN & OPPOSE \\
\hline To protect nature and biological diversity & $4.29^{\mathrm{a}}$ & $3.61^{\mathrm{b}}$ & $2.78^{\mathrm{b}}$ \\
To enjoy beauty and scenery & $4.53^{\mathrm{a}}$ & $4.07^{\mathrm{a}, \mathrm{b}}$ & $3.62^{\mathrm{b}}$ \\
To earn an income & $2.22^{\mathrm{a}}$ & $2.42^{\mathrm{a}, \mathrm{b}}$ & $3.10^{\mathrm{b}}$ \\
As a financial investment & $3.30^{\mathrm{a}}$ & $3.50^{\mathrm{a}, \mathrm{b}}$ & $4.11^{\mathrm{b}}$ \\
For a future homesite & $2.19^{\mathrm{a}}$ & $2.98^{\mathrm{a}, \mathrm{b}}$ & $3.38^{\mathrm{b}}$ \\
To have open space for my family to enjoy & $4.47^{\mathrm{a}}$ & $4.38^{\mathrm{a}}$ & $4.2^{\mathrm{a}}$ \\
As a place of residence & $4.51^{\mathrm{a}}$ & $4.41^{\mathrm{a}}$ & $4.27^{\mathrm{a}}$ \\
For privacy & $4.29^{\mathrm{a}}$ & $4.18^{\mathrm{a}}$ & $4.29^{\mathrm{a}}$ \\
To pass land onto my heirs and other & $3.55^{\mathrm{a}}$ & $3.73^{\mathrm{a}}$ & $3.98^{\mathrm{a}}$ \\
$\quad$ children & & & \\
To take care of land I inherited & $2.84^{\mathrm{a}}$ & $3.39^{\mathrm{a}}$ & $3.49^{\mathrm{a}}$ \\
For farming and agricultural production & $2.19^{\mathrm{a}}$ & $2.93^{\mathrm{a}}$ & $3.32^{\mathrm{a}}$ \\
For production of forest products such as & $1.81^{\mathrm{a}}$ & $2.28^{\mathrm{a}}$ & $2.13^{\mathrm{a}}$ \\
$\quad$ pulpwood or sawlogs & & & \\
For hunting & $1.98^{\mathrm{a}}$ & $2.61^{\mathrm{a}}$ & $2.46^{\mathrm{a}}$ \\
For fishing & $1.75^{\mathrm{a}}$ & $2.17^{\mathrm{a}}$ & $1.66^{\mathrm{a}}$ \\
For recreation, other than hunting and & $3.27^{\mathrm{a}}$ & $3.10^{\mathrm{a}}$ & $2.81^{\mathrm{a}}$ \\
$\quad$ fishing & & & \\
\hline
\end{tabular}

Note. $\quad$ SUPPORT $=$ Supportive Landowners; UNCERTAIN $=$ Uncetain Landowners; OPPOSE $=$ Opposing Landowners. Respondents were asked: "In your opinion, how important are the following reasons for owning your land." Response based on 5-point Likert scale where $1=$ not at all important; 2 =slightly important; $3=$ moderately important; $4=$ important; $5=$ very important. Means (reading across rows) with different superscripts are significantly different at $p<.05$. 
Table 3. Mean response values by landowner cluster for trusted sources of information on vernal pools

Source SUPPORT UNCERTAIN OPPOSE

Maine Department of Inland Fisheries and Wildlife

Maine Department of Environmental

$4.38^{\mathrm{a}} \quad 4.05^{\mathrm{a}} \quad 3.53^{\mathrm{b}}$

Protection

University of Maine

U.S. Fish and Wildlife Service

$\begin{array}{lll}4.26^{\mathrm{a}} & 3.55^{\mathrm{b}} \quad 2.95^{\mathrm{c}}\end{array}$

Maine Audubon Society

Local land trust

Citizen scientist

$4.32^{\mathrm{a}}$

$3.82^{\mathrm{b}}$

$3.35^{\mathrm{b}}$

$4.25^{\mathrm{a}}$

$3.61^{\mathrm{b}}$

$3.25^{\mathrm{b}}$

$4.17^{\mathrm{a}}$

$3.50^{\mathrm{b}}$

$2.83^{\mathrm{c}}$

$3.99^{\mathrm{a}}$

$3.03^{\mathrm{b}}$

$2.70^{\mathrm{b}}$

Maine Coast Heritage Trust

$3.51^{\mathrm{a}}$

$2.57^{\mathrm{b}}$

$2.26^{\mathrm{b}}$

$3.49^{\mathrm{a}}$

$2.81^{\mathrm{b}}$

$2.41^{\mathrm{b}}$

Small Woodland Owners Association of Maine

Private consultant

$3.41^{\mathrm{a}}$

$3.23^{\mathrm{a}}$

$3.39^{\mathrm{a}}$

Town planner

$3.31^{\mathrm{a}}$

$3.12^{\mathrm{a}}$

$3.28^{\mathrm{a}}$

$2.80^{\mathrm{a}, \mathrm{b}}$

$3.05^{\mathrm{a}}$

Neighbors and other landowners

$3.04^{\mathrm{a}}$

$2.18^{\mathrm{a}}$

Note. SUPPORT $=$ Supportive Landowners cluster; UNCERTAIN $=$ Uncertain Landowners cluster; OPPOSE =Opposing Landowners cluster. Respondents were asked "In your opinion, how trustworthy are each of these sources for providing accurate information about vernal pools on your property?' Response based on a 5-point Likert scale with $1=$ very untrustworthy to $5=$ very trustworthy. Means (reading across rows) with different superscripts are significantly different at $p<.05$. 
Table 4. Mean response value by landowner cluster for effective methods for providing information about vernal pools

Method

SUPPORT UNCERTAIN OPPOSE

Fact sheets

$4.19^{\mathrm{a}}$

$3.57^{\mathrm{b}}$

$3.79^{\mathrm{a}}$

$3.33^{\mathrm{a}, \mathrm{b}}$

$3.82^{\mathrm{a}, \mathrm{b}}$

Internet and/or website

$3.80^{\mathrm{a}}$

$2.91^{\mathrm{b}}$

$2.80^{\mathrm{b}}$

Meeting with natural resource professional

$3.71^{\mathrm{a}}$

Town newsletter

$3.56^{\mathrm{a}}$

$2.66^{\mathrm{b}}$

$2.82^{\mathrm{b}}$

Public information session

$3.49^{\mathrm{a}}$

Magazine and newspaper

$3.44^{\mathrm{a}}$

$2.35^{\mathrm{b}}$

$2.91^{\mathrm{b}}$

Talking to citizen scientist

$3.39^{\mathrm{a}}$

$3.00^{\mathrm{a}}$

$2.70^{\mathrm{b}}$

Television program

$2.87^{\mathrm{a}}$

$2.50^{\mathrm{b}}$

$3.00^{\mathrm{a}}$

Talking to neighbors and other property owners

Radio program

$2.85^{\mathrm{a}}$

$2.79^{\mathrm{b}}$

$2.42^{\mathrm{b}}$

$2.67^{\mathrm{b}}$

$1.93^{\mathrm{b}}$

$2.36^{\mathrm{a}, \mathrm{b}}$

Note. SUPPORT $=$ Supportive Landowners cluster; UNCERTAIN $=$ Uncertain Landowners cluster; OPPOSE = Opposing Landowners cluster. Respondents were asked "To what extent do you agree that the following methods are effective ways of providing you with information on vernal pools?" Response based on a 5-point Likert scale where $1=$ strongly disagree; $2=$ disagree; $3=$ neither agree/disagree; $4=$ agree; $5=$ strongly agree. Means (reading across rows) with different superscripts are significantly different at $p<.05$. 


\section{References}

Boon, T. E., and H. Meilby. 2007. Describing management attitudes to guide forest policy implementation. Small-Scale For. 6:79-92.

Brook, A., M. Zint, and R. De Young. 2003. Landowners' responses to an Endangered Species Act listing and implications for encouraging conservation. Conserv. Biol. 17(6):1638-1649. Brugnach, M., A. Dewulf, C. Pahl-Wostl, and T. Taillieu. 2008. Towards a relational concept of uncertainty: About knowing too little, knowing too differently and accepting not to

know. Ecology and Society 13(2). http://www.ecologyandsociety.org/vol13/iss2/art30 Burns, M., and A. S. Cheng. 2007. Framing the need for active management for wildlife mitigation and forest restoration. Society Nat. Resources 20:245-259.

Calhoun, A. J. K., and P. G. deMaynadier, eds. 2008. Science and conservation of vernal pools in the northeastern United States. Boca Raton, FL: CRC Press.

Creswell, J. W. 2009. Research design: Qualitative, qualitative, and mixed methods approaches. Thousand Oaks, CA: Sage.

Davis, M. L. E., and J. M. Fly. 2010. Do you hear what I hear: Better understanding how forest management is conceptualized and practiced by private forest landowners. J. For. 108:321-328.

Dewulf, A., M. Craps, and G. Dercon. 2004. How issues get framed and reframed when different communities meet. A multi-level analysis of a collaborative soil conservation initiative in the Ecuadorian Andes. $J$. Commun. Appl. Social Psychol. 14:177-192.

Dewulf, A., B. Gray, R. Lewicki, L. Putnam, N. Aarts, R. Bouwen, and C. van Woerkum. 2009. Disentangling approaches to framing in conflict and negotiation research: Mapping the terrain. Hum. Relations 62(2):155-193.

Dillman, D. A., J. D. Smyth, and L. M. Christian. 2009. Internet, mail, and mixed-mode surveys: The tailored design method. Hoboken, NJ: John Wiley \& Sons.

Emtage, N., J. Herbohn, and S. Harrison. 2006. Landholder typologies used in the development of natural resource management programs in Australia-A review. Australasian J. Environ. Manage. 13(2):7994.

Erickson, D. L., and R. DeYoung. 1993. Management of farm woodlots and windbreaks: Some psychological and landscape patterns. J. Environ. Systems 22:233-247.

Finley, A. O., and D. B. Kittredge, Jr. 2006. Thoreau, Muir, and Jane Doe: Different types of private forest owners need different kinds of forest management. Northern J. Appl. For. 23(1):27-34.

Fischer, A. P., and J. C. Bliss. 2009. Framing conservation on private lands: Conserving oak in Oregon's Willamette Valley. Society Nat. Resources 22:884-900.

Glaser, B. G., and A. L. Strauss. 1967. The discovery of grounded theory: Strategies for qualitative research. Chicago, IL: Aldine.

Goffman, E. 1974. Frame analysis: An essay on the organization of experience. New York, NY: Harper and Row.

Gray, B. 2003. Framing of environmental disputes. In Making sense of environmental disputes: Concepts and cases, ed. R. J. Lewicki, B. Gray, and M. Elliott, 11-34. Washington, DC: Island Press.

Gray, B. 2004. Strong opposition: Frame-based resistance to collaboration. J. Commun. Appl. Psychol. 3:166176.

Groffman, P. M., C. Styliniski, M. C. Nisbet, M. Duarte, R. Jordan, A. Burgin, M. A. Prentali, and J. Coloso. 2010. Restarting the conversation: Challenges at the interface between ecology and society. Front. Ecol. Environ. 8(6):284-291.

Hogl, K., M. Pregernig, and G. Weiss. 2005. What is new about new forest owners? A typology of private forest ownership in Austria. Small-Scale For. Econ. Policy 4(3):325-342.

Jennings, S. M., and I. E. van Putten. 2006. Typology of non-industrial private forest owners in Tasmania. Small-Scale Forest Econ. Manage. Policy 5(1):37-56.

Jick, T. D. 1979. Mixing qualitative and quantitative methods: Triangulation in action. Admin. Sci. Q. 24:60611.

Karppinen, H. 1998. Values and objectives of non-industrial private forest owners in Sweden. Silva Fenn. 32(1):43-59.

Kittredge, D. B. 2004. Extension=outreach implications for America's family forest owners. J. For. 102(7):1518.

Kline, J. D., R. J. Alig, and R. L. Johnson. 2000. Fostering the production of nontimber services among forest owners with heterogeneous objectives. For. Sci. 46:302-311.

Kuuluvainen, J., H. Karppinen, and V. Ovaskainen. 1996. Landowner objectives and non-industrial private timber supply. For. Sci. 42(3):300-309.

Lakoff, G. 2010. Why it matters how we frame the environment. Environ. Commun. 4(1): 70-81. 
Lewicki, R. J., B. Gray, and M. Elliott, eds. 2003. Making sense of intractable environmental conflict. Washington, DC: Island Press.

Madsen, L. M. 2003. New woodlands in Denmark: The role of private landowners. Urban For. Urban Greening 1(3):185-195.

Merriam, S. B. 2009. Qualitative research: A guide to design and implementation. San Francisco, CA: John Wiley \& Sons.

Minsky, M. 1975. A framework for representing knowledge. In The psychology of computer vision, ed. P. H. Winston, 211-277. New York, NY: McGraw-Hill.

Morgan, D. E., and J. K. Calhoun. 2012. The Maine municipal guide to mapping and conserving vernal pools. Gilsland, Maine: Maine Audubon Society.

Napier, T. L., and S. M. Camboni 1998. Attitudes toward a proposed soil conservation program. J. Soil Water Conserv. 43: 186-191.

Neale, M. A., and M. H. Bazerman. 1985. The effects of framing and negotiator overconfidence on bargaining behaviors and outcomes. Acad. Manage. J. 28:34-49.

Nisbet, M. C., and D. A. Scheufele. 2009. What's next for science communication? Promising directions and lingering distractions. Am. J. Bot. 96(10):1767-1778.

Reading, R. P., T. W. Clark, and S. R. Kellert. 1994. Attitudes and knowledge of people living in the greater Yellowstone ecosystem. Society Nat. Resources 7:349-365.

Rosenberg, S., and R. D. Margerum. 2008. Landowner motivations for watershed restoration: Lessons from five watersheds. J. Environ. Plan. Manage. 51(4):477-496.

Schön, D. A., and M. Rein. 1994. Frame reflection: Toward the resolution of intractable policy conflicts. New York, NY: Basic Books.

Strauss, A. C., and J. M. Corbin. 1990. Basics of qualitative research: Grounded theory procedures and techniques. Thousand Oaks, CA: Sage.

Tversky, A., and D. Kahneman. 1981. The framing of decisions and the psychology of choice. Science 211:453458.

Van Herzele, A., and P. Van Gossum. 2008. Typology building for owner-specific policies and communications to advance forest conversion in small pine plantations. Landscape Urban Plan. 87:201-209.

van Lieshout, M., A. Dewulf, N. Aarts, and C. Termeer. 2011. Do scale frames matter? Scale frame mismatches in the decision making process of a "mega farm" in a small Dutch village. Ecol. Society 16(1):38. http://www.ecologyandsociety.org/vol16/iss1/art38

Vincent, S. G., and T. E. Shriver. 2009. Framing contests in environmental decision-making: A case study of the tar creek (Oklahoma) Superfund site. Am. J. Environ. Sci. 5(2):164-178. 